\title{
An Integration Model of the Impact of IT Investment Announcements on Firm Market Value
}

\author{
Lu Zhang \\ School of Economics and Management, Tsinghua University \\ Beijing100084, China \\ Tel: 86-10-5153-4734 E-mail: zhang12.03@sem.tsinghua.edu.cn \\ Jinghua Huang \\ School of Economics and Management, Tsinghua University \\ Beijing100084, China \\ E-mail: huangjh@sem.tsinghua.edu.cn \\ Pan Wang \\ Department of Automation, Tsinghua University \\ Beijing100084, China \\ E-mail: wzp19890328@yahoo.cn
}

Received: November 23, $2011 \quad$ Accepted: December 12, $2011 \quad$ Published: February 1, 2012

doi:10.5539/ibr.v5n2p59

URL: http://dx.doi.org/10.5539/ibr.v5n2p59

This paper is supported by the National Science Foundation of China (70831003)

\begin{abstract}
Large amounts of resources have been, and will continue to be, invested in information technology (IT). The current paper establishes an integrative model of the impact of IT investment announcements on firm market valueby reviewing and analyzing several papers of empirical research. The impact factors are divided into four parts:IT investment characteristics, firm characteristics, competitive environment (including industry characteristics and partner characteristics), and country characteristics. In addition, the current article applies the integrative model to guide future research by proposingcorresponding hypotheses. The objective of the paper is to help scholars further understand the status and limitations of relative studies to facilitate further research. The proposed hypotheses providefirms with scenarios that can get the most benefit out of IT investment, thus guiding scholars on empirical research as well as strategic decision makers in organizations.
\end{abstract}

Key words: IT investment announcements, IT investment value, Firm market value, Impact factors

\section{Introduction}

Thus far, substantial resources have been invested in information technology (IT) (Teo, Wong, \&Chia, 2000). However, IT impact on firms is still inconclusive.Many studies have attempted to establish the relationship between IT investment and enterprise performance (Aral\& Weill, 2007); however, the conclusions obtained from empirical studiesare inconsistent. Some results indicate a positive correlation between IT investment and firmperformance (Brynjolfsson\&Hitt, 1996, Harris \& Katz, 1991), but other studies have found no significant relationship between the two (Berndt \& Morrison, 1994, Loveman, 1994). Recent researches indicate that when IT investment with specific attention enters at the proper opportunity, and acquires better management and proper mutually complementary investment, more business values will be produced (Barua\&Mukhopadhyay, 2000). Many research methods can be used for relevant research; the event study method (Richardson \&Zmud, 2002) is one of them. Event study method has been widely used in the accounting and financial fields to calculate the impact of a specific event on an enterprise market value (Ball \& Brown, 1968, Brown \& Warner, 1985). In the information system (IS) research field, an event refers to IT investment announcements (Richardson \&Zmud, 2002). These IT payoff studies 
focus on two problems: (1) Does IT payoff?and(2)In which conditions can IT investment obtain the maximum return (Richardson \&Zmud, 2002, Dehning, Richardson, \&Zmud, 2003, Oh, Kim, \& Richardson, 2006)? In literature, firm market valueis used as the measure ofan IT investment payoff. For the first research problem, the conclusions obtained from previous studies areinconsistent. The second research problem tried to explain the source of the inconsistent impact of IT investment and to determine when an IT investment is efficient.

For the two issues mentioned above, the current article has three targets: (1) review the literature for empirical studiesand summarize the limitations of previous research on the impact factors of IT investment values, (2) propose an integration model of the impact of IT investment announcements on firm market value based on relevant theory and existing studies on the impact of IT investments on firmmarket value, and (3) propose relevant hypotheses to guide future research.

In collecting literature, the authors used "Information Technology" or "Information Systems," "e-commerce" or "e-business," and "announcement" as keywordsto search in all ISI Web databases. The authorsobtained 24 related articles from a total of 206 articles by finding and reading the papers one by one. The citation databases of SCI-Expanded and SSCI in the ISI Web of Knowledge started their collection from 1994 to 1998.For the literature before1998, the authors mainly filteredthese using the references of existing literature. The authorsobtained 25 related literaturesfrom the period 1993-2007.

First, the article systematicallyreviewsempirical studiesin the literature to look into the factors of theseempirical studies andthen summarize their limitations. Second, an integration model is proposed based on the related theory and existing empirical studies. This article also proposesrelevant hypotheses to guidefuture research based on the integration model. Finally, the contribution and limitations of this articleare presented.

\section{Review of Empirical Research}

\subsection{Literature Review}

The author divided the literature into six categories based on the research objects to more clearly understand and compare the literature before reviewing the empirical studies. The articleconducts the following statistics based on the research objects and published journals (Table 1).

The first category is investment announcements related to IT. Researchers get the announcements by using information technology (IT) and information system (IS) as the keywords to search. However, the research conclusions are not consistent in these announcements. Dos Santos, Peffers, \&Mauer(1993)Im, Dow, \& Grover(2001)and Richardson and Zmud (2002)find no significant relationship between IT investment and firm market value.Chatterjee,Pacini, \&Sambamurthy(2002),Dehning,Richardson, \&Zmud (2003),Dardan, Stylianou, \& Kumar (2006), Oh, Kim, \& Richardson(2006), and Meng and Lee (2007)indicatethat IT investment can bring excess profits for the firm. In addition, some of the literaturealso studythe impact of IT investment characteristics, firm characteristics, and industry characteristics on the changes in firm market value.Dos Santos et al.find that the market has a higher evaluation for innovative IT investment compared to the following IT investment (Dos Santos et al, 1993). Imet al. (2001) examine the impact of industry, firm size, and announcement time on stockprices. Richardson and Zmud (2002) find the strategic role of IT investment announcements has a significant effect on abnormal returns. Dehning et al.(2003) findthat when companies have strategic transformation in the role of IT investments, they can often get significant excess returns. Oh et al.(2006)find that business growth opportunities, uncertainty, the strategic role of IT, the disclosing party, the interactionrelationship betweenuncertainty and strategic role of IT investments, and that between uncertainty and asset specificity have a significant impact on the abnormal return offirms. Meng and Lee (2007) examine the industry, firm size, and business type, and find that these three factors may affect the value of IT investment.

The second category is e-business announcements. This category of announcements is about firms developing e-commerce activities or expressing the intention to develop e-commerce activities.Subramani and Walden (2001), Lee, Cho, \& Lee (2002), Dehning,Richardson, \&Urbaczewski(2004), Ferguson, Finnb, \& Hall (2005) and Lin, Jang, $\&$ Chen(2007)show that e-commerce announcementshave a positive effect on firm market value. Dewan and Ren (2007) find that when the changes in risk are controlled, the impact of e-commerce announcements on the stock price is not significant. The literatureconducts research onthe impact of the type of e-commerce, innovation, firm size, market size, and other attributes of corporate experience on firm market value.

The third category is enterprise system announcements. These announcements refer to enterprise resource planning (ERP) systems, customer relationship management (CRM) systems, supply chain management (SCM) systems, and decision support systems. Hayes, Hunton, \& Reck(2001)studythe market reaction to ERP systems and find that investors give a positive evaluation on ERP implementation announcements. They also conducted a research on the 
market reaction to theinteraction of firms' health degree and firm size.Aside from the ERP characteristics, theyalso introduce supplier factors. The research results indicate that a smallhealthy firm will gain higher returns, and choosing well-knownsuppliers enhances the firm's benefits. Ranganathan and Brown (2006) employ 116 ERP investment announcements during the period of 1997-2001. They find significantly positive abnormal returns in the events window. They also use regression models to examine the number of ERP module implements, the implementation of the range, and the impact of the supplier on abnormal returns. The regression modelsindicatethat the first two variables are positively correlated with abnormal return.

The fourth category isannouncements related to knowledge management. This type contains the announcements about knowledge sharing and knowledge management system. Sabherwaland Sabherwal (2005) conduct a research on knowledge management announcements based on IT. They find thatthe abnormal returns of firms have a significant relationship withfirm size, Return on sales (ROS), synergy of firm effectiveness and knowledge management, firm stability, and diversification. Based on103 knowledge management announcements from 1995 to 2002, Sabherwal and Sabherwal (2007) find that firmsize, knowledge management strategy, and synergy of knowledge management strategy have a significant relationship withabnormal returns, whereas there is no significant correlation with the knowledge management process, source, andusers.

The fifth category is IT outsourcing announcements. This category mainly refers to outsourcing activities about IT, IS, and e-commerce. The researchers explain the advantages and disadvantages of outsourcing on firmsby learning the impact of IT outsourcing announcementson firm market value. Hayes, Hunton, \&Reck (2000) and Peak, Windsor, \& Conover (2002)indicate thatIT outsourcing cannot bring excess profits. However, Oh and Gallivan (2004), Oh, Gallivan, \& Kim (2006), and Agrawal, Kishore, \&Rao (2006) point out that there is a significant relationship between IT outsourcing andfirm market value. These studies also find that industry, scale of outsourcing contracts, specificity of IT resources, difficulty of supervision, firm size, and supplier size have significant impacts on abnormal return.

The sixth category is IT staff announcements. This typecontains announcements about IT workers, management staff, CIO, and so on. Existing studies only focus on the level of CIO appointments because information is limited to CIO appointments. Chatterjee, Richardson, \& Zmud (2007) examine themarket reaction to the announcements thatfirmshave created CIO positions. The creation of CIO positions significantly enhancesthe market returnof firms. Khallaf and Skantz (2007) employ 461 CIO appointment announcements from 1987 to 2002, and find no significant difference between created and appointed CIO and appointed CIO alone. They also find thatthe market will punish firmsthatdo not access the advantage of the CIO potential strategy in a timely manner. The market reaction to the quality of CIO appointmentsis also examined.

\subsection{Limitations of Existing Research}

Althoughexisting studies have examined the impact of IT investments on firm market value from various dimensions, there are some limitations. First, the time interval of the sample used in literature is too short, thus further validation of these research results is necessary to determine whether they could be applied in present IT investments. Second, certain limitations still exist in the following aspects in existing research.

Most studies belong to the general research on IT investments or e-business investments, and few studies on concrete IT investment projects are available. When the concrete projects are not limited, their special attribute is difficult to concretize to measure their influences on IT investment values. Therefore, various IT investment projects should be concretized, and the character factors and weights influencing the enterprise market value should be tested, aiming at various concrete investment projects (Dos Santos et al., 1993, Im et al., 2001, Hayes et al., 2001). For example, ERP systems provide a unified information platform that improves the internal efficiency offirms, saves costs, and providesopportunities for future application.CRM systems achieve a better understanding of customer preferences to gain higher customer satisfaction and,ultimately, improve business performance. The strategic goals, scale of implementation, time needed to implement, technology during the implementation, and process of producing value between the two systems are different. The impact of theinfluencing factorson IT producing business value is also not the same. Thus, the specific characteristics of ERP and CRM should be discussed. Based on a certain theory, the attributes that may affect the business value will be found.

In the aspect of firm characteristics, firm attributes play a vital role during IT investment producing value, although empirical studies employingfirm characteristics are available. The kind of firm characteristics that has great impact on IT investments is difficult to identifybecause IT investments are broad. Thus, for specific IT investments, the kind of firm characteristics that will systematically influence IT investment value can be analyzed based on theory and previous studies (Dos Santos et al., 1993, Hayes et al., 2000). For instance, the purchase of IT hardware has little connection with the health degree offirms. However, the implementation of large enterprise systems such as 
ERP may greatly exceed the budget because of some uncontrolled factors. This situation may lead to a capital chain break if the health degree of firms is too low. Eventually the project will fail. Other studies also point out that IT authority, IT management ability, IT experience, and investments of complementary resources could influence IT investment value. For example, the innovative IT investment of Wal-mart and K-mart may have a different impact on market value (Oh et al., 2006).

All firmactivities carried out in a certain external environment. Thus, the influence of the external environment should be considered. In previous studies, the industry is always taken as the control variable; however, it is coarsely classified, and few researchers study how the industrial character adjusts with the IT investment value. First, firms in highlycompetitive industries which adopt IT investment aiming to save costs cannot achieve a sustainable competitive advantage. The burden for this part is often taken by the consumers for the sake of competition. Therefore, it is necessary to define the industry more precisely in order to study what kind of IT investment can bring more effective returns (Dos Santos et al., 1993, Im et al., 2001). Second, with the increasing relationship between firms, partners play an important role in the process of IS implementation. However, little research is available in this area. Only some paperson ERP and IT outsourcing consider suppliers as a factor which adjusts abnormal return. Apart from the two factors above, the country's culture, infrastructure, and other features are likely to impact IT investment value. However, there is only one article of research on this aspect (Meng and Lee, 2007). The article compares the difference of IT investment value between China and the United States, and choosesonly one country as a representative. The general conclusions are questionable.

From the discussion, the studieson the aspect of IT investment characteristics, firmcharacteristics, and external environment are shown to be insufficient. Studies that simultaneously consider all aspects are almost nonexistent. Thus, there are two research directions for future studies. One is further study that focuses on IT investment characteristics, firm characteristics, or external environment. The impact of an IT investment from one dimension can be measured based on the controlling variables in the other two dimensions. Another direction is to simultaneously consider the impact of IT investment characteristics, firm characteristics, andexternal environment, although the interaction between the three aspects cannot be neglected (Oh et al., 2006).

Thus, the current article proposes an integration model of the impact of IT investment announcements on firm market value based on the summary of existing literature and limitation analysis.

\section{Integration Model}

The different IT investment announcements will have different impactson firm market value according to the discussion above. In addition, the unique characteristics of an individual firm can influence the IT producing value. As mentioned above, the external environment also plays an important role in determining the business value produced by IT. Thus, the external environment is divided into competitive environment and country characteristics. The competitive environment contains industry characteristics andpartner characteristics. Based on the related theory and empirical studies, the current article proposesan integrated modelthat explains the impact of IT investment characteristics,firm characteristics, industry characteristics, partner characteristics, and country characteristics on firm market value (Figure 1). The impacts of these five characteristics onfirm market value will be discussed later.

\subsection{IT Investment Characteristics}

The differences in IT investment characteristics may bring different reactions (Oh et al., 2006). The factthatsome IT projects will not succeed is indisputable (Lucas, 1999). Most IT project actually have various risks, such as financial risk, technical risk, political risk (Clemons, Thatcher, \& Ro, 1995), and agent risk (Gurbaxani and Whang, 1991). These risks may cause the IT project to fail, and the risk of project failure will reduce the comprehensive evaluation of the IT projects. Existing empirical studies classify IT investment from multiple dimensions. Based on the literature theory and empirical study, IT investment is divided aspresented below.This article also proposes some hypotheses.

The first dimension is based onthe first-mover theory andprevious studies (Mascarenhas, 1992). In this caseIT investment is divided into innovative and non-innovative investments. An innovative investment will be defined as the investment represented the first use of a technology among firms competing in that industry, or the investment would result in a new product or service based on information technology, or the investment would result in the development of new information technology for the industry (Dos Santos et al., 1993). In economics, one of the ways firmscan obtain higher income is to seize an opportunity earlier than other firms (Schumpeter, 1950). This means that the adoption of the new IT application will gain economic rents. Therefore,the innovative IT investments will bring higher returnsforinvestors.Technology leaders can gain first-mover advantage, such as the reputation of technical leadership and favorable market position, better access to scarce resources, and strengths in the learning 
curve, which can give firms a competitive advantage (Porter, 1985). The researchers find that only innovative IT investments can produce a competitive advantage in the case study (Keen, 1988, Porter and Millar, 1985).Dos Santos et al.(1993)also find that only innovative IT investment can increase firm value. Dehning et al.(2003) also find that the strategic role of IT investment in implementationsthat are ahead of the competitorswill get higher return. Thus, innovative IT investment can increase firm market value.

\section{Hypothesis 1a: Innovative IT investment announcements will increase firm market value more.}

The second dimension is based on the resource-based view (RBV). According to the concept of Schein and Zuboff (Zuboff, 1988, Schein, 1992), IT investment strategic role can be divided into four categories: automate, informate-up, informate-down, and transformation. Automate is defined as replacing human labor in automating business processes. Informate-up is defined as providing information about business activities to senior management; Informate-down is defined as providing information about business activities to employees across the firm. Transform is defined as fundamentally redefining business and industry processes and relationships.According to RBV, resources which can generatea sustainable competitive advantage must have four properties: value, rare, inimitable, and non-substitutable (Melville, Kraemer, \&Gurbaxani, 2004). These resource attributes build the level of competitive advantage. If the resources are valuable and scarce, firmsthat own the resources can obtain benefits. The resources then provide firms short-term competitive advantage. If the resources areinimitable and non-substitutable, firms can keep competitorsfrom imitating and copying the resources. This advantage is then sustainable (Wade and Hulland, 2004). An automate IT investment is easy to imitate; thus, a competitive advantage is difficult to maintain. When the IT investment occupies the main part in the industry, investors will tend to regard it as eligible elements of competition. Thus, automate IT investment often cannot bring substantial increase in income or value. Information-up and information-down IT investmentshave the potential to improve competitive advantage, but these are easy to imitate and can only, therefore, improve business performance in the short-term. IT investments that play the role of IT strategic transformation to redefine business processes and relationshipsare are difficult to imitate. Thus, they can maintain and sustain competitive advantages. Richardson and Zmud (2002)findthatthe abnormal return of firms is positively related to the strategicrole of IT investment. The results of Dehninget al. (2004) and Ohet al.(2006) support this conclusion. Therefore, transformation IT investment can bring greater value for investors.

\section{Hypothesis 1b: Transformation IT investment announcements will lead to higher excess return.}

The thirddimension isasset specificity based on the transaction cost theory. This dimension classifies IT investment according tothe investment's asset specificity. An asset is considered to have asset specificity if it is not easily used in another situation. Asset specificity is one of the important dimensions of IT assets. The transaction cost theory points outthat transactionswith high asset specificities will lead to very strong dependence, which can produce high transaction costs. High specific IT assets will bring trading difficulties and agent risks, which will eventually lead to project failure. They also bring additional cost of supervision. Oh et al. (2006)also find thatasset specificity of outsourcing have a negative relationship with investor response. In summary, investors show a negative attitude on IT investment withstrong asset specificity.

\section{Hypothesis 1c:IT investment announcements with high asset specificity have a negative correlation with firm market value.}

The fourthdimension is based on competition agility, organizational integration, and the option value theory. This dimension distinguishes IT investment from the breadth and depth of implementation. The breadth refers to the number of sites that project envelops, defined here in terms of business divisions and geographies. The depth refers to the types of IT modules a firm chooses to purchase. The greater the breadth and depth of the platform IT provides, the more connectivity there will be. These electronic connections can provide a platform where we can share ideas, collect rare resources, and facilitate business processes (Chatterjee et al., 2002). Through collaboration and knowledge sharing, companies can establish and maintain their competitive responsiveness, diversity, and innovation competition. From the organizational integration perspective, the firmthat tries to integrate business processes and data often implements IT in multiple business units or areas. Thus, this firm can get more profit from organizational integration compared with other firms which implement IT in a single department or location. In addition, an IT investment of greater breadth and depth hasmore option gains. The investment in building IT platforms through the integration of functional units, branch offices, activities, and information flow of external partners expands the scope oforganizations (Sambamurthy and Bharadwaj, 2003). Chatterjeeet al.(2002)find that IT infrastructure investments can provide a higher abnormal return compared with IT application investment. Ranganathan and Brown (2006) find that the number of functional modelsfor ERP implementation has a positive correlation withfirm market value. They also indicatethat ERP implementation in a larger scale can bring significant 
abnormal returns, whereas a smaller scale cannot produce abnormal return.Based on these theories and the conclusion of the empirical study, the depth and breadth of IT investment has a positive impact on the valuethat the IT investment brings.

\section{Hypothesis 1d: The breadth and depth of IT investment has a positive correlation with the abnormal return which IT investment announcements bring.}

\subsection{Firm Characteristics}

IT investment payoff of firms shows greater difference (Aral and Weill, 2007). Statistical conclusions show that most IT investment payoffscan be explained by firm characteristics (Brynjolfsson and Hitt, 1995). These studies conclude that differences in the quality or nature of firms may also cause differences between IT investment values. Research in the field of accounting and finance has already treated it as one of the important factors (Fama and French, 1992). Some researchers introduce firm characteristics as an independent variable to study its effect on the value of IT investments based on research in other fields combined with the properties of IT investments. Based on existing research and relevant theory, firm characteristics are divided as presented below, and the corresponding hypotheses are proposed.

The first dimensionis based on the information transmission theory, which classifiesfirms according to its scale. Based onthis theory and previous research in other fields, the financial information of small firms is more valuable than those of large firms because of the asymmetry of information. Large firms are the focus of media and analysts. Thus, more information related to large firmsis available even before the release of financial information. However, small firms have less public information. Therefore, the market will have a more obviousresponse toinformation that a small firm releases. Some studies point outthat small firms can get opportunities from IT investments, and this opportunity can maintain long-term competitiveness (Hayes et al., 2000). Hayes et al.(2000)also find that the market has a significant positive response to IT outsourcing announcements from small firms, but has no response tothose of large firms. Im et al. (2001) and Richardson and Zmud (2002)reach a similar conclusion.

\section{Hypothesis 2a: Firm scale has a negative correlation with the abnormal return which IT investment announcements bring.}

The second dimension is based on the growth opportunity offirms. A number of financial and accounting research show that a firm's growth rate will affect the reaction to announcements. Firm market value depends on the growth of existing assets and future space. Thus, the growth opportunity of firms is the key determinant of the market reaction(Chatterjee et al., 2002, Fama and French, 1992, Dewan and Min, 1998). A high growth rate means that investors believe the company has great growth potential. In contrast,a low growth rate means that investors are not hopeful about the firm's growth. High-growth companies tend to reinvest their income in positive NPV projects. The market considers high-growth firms to have a better ability to manage investments (Smith and Watts, 1992). Although the empirical conclusions are not inconsistent, Chatterjeeet al. (2002)point out that the growth rate of firms has a negative correlation with the abnormal return ${ }^{0}$. However, Oh et al. (2006) find that the growth rate of firms has a positive correlation with the abnormal return. Based on the above discussion, the growth rate of corporations is believed to have a positive correlation with the impacts of IT investment announcements.

\section{Hypothesis 2b: Firm growth rate has a positive correlation with the impact of the firm market value from IT investment announcements.}

The third dimension is based onfirm risk. Firm risk can be measured as the variance of stock return, ROE, ROA et al. IT investment plays a crucial role in reducing firm uncertainty from the perspective of information processing. IT can help firms respond more proactively and in a timely manner to external and internal risks (Galbraith, 1977, Gurbaxani and Whang, 1991). From the information transmission perspective, firm uncertainty is actuallythe investors' lack of confidence in the firm. IT investment announcements send signals to investors of the willingness of managers to increase profitability and generate cash flow. Oh et al. (2002) point out that the response to IT investment announcements has a positive correlation with firm uncertainty. Thus, IT investment announcements by high-risk firms will bring greater benefits.

\section{Hypothesis 2c: IT investment announcementsby high-risk firms will bring greater benefits.}

The fourth dimension is based on thetop management's commitment to IT investments. Generally speaking, the senior leadershipthat is able to promote, support, and guide IT investment can improvethe IT investment value (Ross, Beath, \& Goodhue, 1996, Armstrong and Sambamurthy, 1999). Neo(1988)indicatesthat the use of strategic ITsupported by top management will give firms a competitive advantage. The impact of IT investments on firm performance or competitive position can weaken when supportis lacking, even if a large amount is invested. In contrast, a strong top management commitment forIT investment can improve firm performance. Therefore, the top 
management's commitment to IT investment has a positive correlation with the market value.

\section{Hypothesis 2d: Firms with strong top management commitment to IT investment will get more excess return.}

\subsection{Competitive Environment}

Firms are always run in a commercial environment, which is calledthe competitive environment. It contains industry characteristics and partner characteristics. Industry characteristics include competitive, regulatory, technological change, product replacement cycle, and other factors which limitIT investment value (Kettinger, Grover, Guha, \&Segars, 1994, Kraemer, Dedrick, \&Yamashiro, 2000, Hill and Scudder, 2002, Devaraj and Kohli, 2003, Jorgenson, Ho, \&Stiroh, 2003). When IT investment crosses organizational boundaries, the business process, IT resources, and non-IT resourcesof trading partners account for a place during the production of IT investment value(Chatfield and Yetton, 2000, Williams and Frolick, 2001, Mukhopadhyay and Kekre, 2002). Therefore, industry characteristics and partner characteristics are contained in a competitive environment. This will be described in detail in the following section.

\subsubsection{Industry Characteristics}

The relationship between IT investment and firm performance is not only influenced by internal factors, such as the firm's growth rate and the degree of support for IT investments, but also by environmental factors (Wade and Hulland, 2004). Industry characteristics limit the acquisition and successfulapplication of IT (Melville et al., 2004). Thus, research on industry characteristics will clarify the conditions under which IT investment can produce maximum benefits. Based on existing literature and relevant theories, industry characteristics are divided as presented below; Corresponding hypotheses arealso proposed.

The first dimension is in accordance with the competitive degree of the industry, which can be measured as Herfindahl-Hirschman Index, CR4. In a highly competitive market, firms may applyIT more effectively. However, the profit margins may decline. The value they get from the use of IT may be lost because of competition. In contrast, in a mild competitive environment, firms may improve profit marginswithout increasing productivity. Combined with existing empirical evidence, Melville et al.considerthat the higher the level of industry competition, the lower the margin obtained from IT (Melville et al., 2004). Thus, when the degree of industry competition is low, IT investment announcements offirms will lead to greater gains.

\section{Hypothesis 3a: IT investment announcementsby firms in a low-degree competition industry will lead to excess} gain.

The second dimension isin accordance with the rolesthat IT occupies. The strategic roles of IT in the industry are classified into four types: automate, information-up, information-down, and strategic transformation. Researchsuggests that the value chain's organizational structure will change whenstrategic transformation becomesmainstream in the industry (Dehning et al., 2003). The market will divide the industry members into strategic groups, with each group representing a unique competitive strategy and having a different level of profitability. More importantly, the entire industry produces more profit. Announcing IT investment in an IT-enabled transformation industry sends a signal thatthe firm is a member of the strategy team who has better profitability. Therefore, the firmsthat announce IT investment in the IT-enabled strategic transformation industry will get higher excess return.

\section{Hypothesis 3b: Firms that announce IT investment in the IT-enabled strategic transformation industry will get} higher excess gain.

\subsubsection{Partner Characteristics}

IT blurs organizational boundaries. Many firms are linked through electronic networks and software applications, as well as the merger of their business processes (Hammer, 2001, Straub and Watson, 2001, Mukhopadhyay and Kekre, 2002, Basu and Blanning, 2003). Thus, trading partners have an impact on the production of IT investment value (Clemons and Row, 1993, Bakos and Nault, 1997, Chatfield and Yetton, 2000). For example, the inefficient business processes of trading partners and obsolete technology limit the acquisition of business values of cross-organizational IT systems. In some cases, this will encourage firms to cooperate with partners for them to improve together (Williams and Frolick, 2001). Based on existing research and related theories, the partner characteristics are divided as presented below, and the corresponding hypotheses are proposed.

The first dimension is in accordance with the partners' degree of support forIT implementation. Partner resources, including IT and non-IT resources, and business processes are important factors that can drive firmsto implement IT successfully (Riggins andMukhopadhyay, 1994). The successful implementation of SCM and other firm systems largely depend on the level of IT ofthe partners andthe senior leadership's support. Thus, the higher the support of 
the partners, the higher the likelihood of successful implementation and thegreater the benefits gained fromit. This will lead to a higher increase in firm market value.

\section{Hypothesis 4a: The partners' degree of support for IT investment has a positive correlation with the abnormal return which IT investment announcements bring.}

The second dimension isin accordance with the power of firms. Although there are many concepts of power, in the context of partnership, it is explained as market power that controlsresources and information (Melville et al., 2004). One example of an extreme case is the implementation of IT investment in a monopoly position. The firm has significant market power which controlsresources and information, and its partners cannot share the benefits of the investment. Thus, the monopoly will get all the benefits. As Horton describes, power is essential for strategy and information systems (Horton, 2003). According to Jasperson, Carte, Saunders, Butler, Croes, \&Zheng (2002), "IT innovation and the introduction can be seen as a process during which the stakeholder groups use their power purposefully to influence the nature of system." IT strengthens and consolidatesthe differentiationin power (Jarvenpaa and Leidner, 1998). Therefore,IT investment announcementsby firms with great power will get a higher excess return.

\section{Hypothesis 4b: IT investment announcementsby firms with great power will get a higher excess gain.}

\subsection{Country Characteristics}

The last characteristics are country characteristics. They are expressed as the specific factors which limit IT investment valuein a country or between countries. They include government promotion, technology development, the information industry, IT talent, information infrastructure, and mainstream IT culture. For example,firms in developing countriesfaceIT limitation applied in education, personnel, infrastructure, and culture ${ }^{0}$. Based on existing research and related theories, country characteristics are divided as presented below and corresponding hypotheses are proposed.

The countries are divided into developed and developing countries. Based on the catching-up theory, the technology development in developing countries lags behind those of developed countries. This situation provides the firms of developing countries a good opportunity to identify the most effective technology and the optimal time of adoption. Thus, failure risk will be significantly reduced. On the other hand, even if the technologies are not the most advanced, they are very innovative in the local markets of developing countries. Based on this theory, IT investment in developing countries will gain higher returns. Meng and Lee (2007) indicate thatthe abnormal return IT investment announcements bring in China is significantly positive. However, abnormal return in the United States is not significant. Thus, IT investment in developing countries can achieve higher abnormal return.

Hypothesis 5: IT investment announcements by firms in developing countries can achieve higher abnormal return.

\section{Methodology}

An event study is a statistical method to assess the impact of an event on the value of a firm, such as its mergers, acquisitions, earnings announcements, refinancing behavior, etc. The impact could be reflected in the following indicators: mean price effect, the change of variance of market return (reflecting the change in stock price volatility), stock volume change, business (accounting) performance changes. The event study method has been widely used in economics, finance and accounting. For example, in the field of accounting, effects of earnings announcement on stock price have been closely watched. In the legal and economic fields, the event study method has been used to test the regulatory effect, and to assess the liability losses and so on.

The event study method includes two time windows, one is the event window, the other is the estimation window. The event window is a period used to test whether there is stock price's abnormal reflection when the events happen. The estimation window is a period used to estimate expected normal return or estimate the parameters of models. The event study method can use many models to estimate the expected normal return, such as constant mean return model, market model, and Arbitrage Pricing Theory (APT) model. Since the application of market model is much easier than APT model and the effectiveness of market model is better than constant mean return model and as good as APT model, majority of studies have employed market model in the event study method (Brownand Weinstein 1985). Thus, we also use market model in our study.

Market model is a statistical model which associates a stock return with market return, which is shown as follows:

$$
\mathrm{R}_{\mathrm{it}}=\alpha_{\mathrm{i}}+\beta_{\mathrm{i}} \cdot \mathrm{R}_{\mathrm{nt}}+\xi_{\mathrm{it}}
$$

$\alpha_{\mathrm{i}}$ and $\beta_{\mathrm{i}}$ are estimated market model parameters. $\beta_{\mathrm{i}}$ means sensitivity of stock $\mathrm{i}$ to market return, while 
$\alpha_{\mathrm{i}}$ depends on the characteristics of stock i. Here, $t$ represents any days in the estimation window. $R_{i t}$ and $R_{n t}$ are stock $\mathrm{i}$ 's return and market return respectively on the $\mathrm{t}$ day in the estimation window.

Using $\alpha_{\mathrm{i}}$ and $\beta_{\mathrm{i}}$ obtained from formula 3, we can predict the expected normal return $\mathrm{R}_{\mathrm{i} \mathrm{T}}^{*}$ of stock $\mathrm{i}$ on the $\mathrm{T}$ day in the event window with formula 4.

$$
\mathrm{R}_{\mathrm{i} \mathrm{T}}^{*}=\alpha_{\mathrm{i}}+\beta_{\mathrm{i}} \cdot \mathrm{R}_{\mathrm{mT}}
$$

Here, $T$ represents any days in the event window; $R_{\mathrm{m}}$ represents market return on the T day; $R_{\mathrm{i}}^{*}$ represents the expected normal return on the $\mathrm{T}$ day.

Further, we calculate the abnormal return $\left(\mathrm{AR}_{\mathrm{i}} \mathrm{T}\right)$ of stock $\mathrm{i}$ on the $\mathrm{T}$ day in the event window:

$$
A R_{\mathrm{i} T}=R_{\mathrm{i} T}-R^{*}{ }_{\mathrm{iT}}
$$

Here, $R_{i} T$ is the real return of stock $i$ on the $T$ day in the event window.

According to the definition of Judge et al (1988), we calculate the variance of the abnormal return of stock $\mathrm{i}$ on the $\mathrm{T}$ day in the event window as follows:

$$
\operatorname{VAR}\left(\operatorname{AR}_{\mathrm{i}} \mathrm{T}\right)=\left(\sigma_{i}^{2}\left[1+\frac{1}{L_{1}}+\frac{\left(R_{m \tau}-\overline{R_{m}}\right)^{2}}{\sum_{t=T_{0}+1}^{T_{1}}\left(R_{n t}-\overline{R_{m}}\right)^{2}}\right]\right)
$$

$\sigma_{i}$ is the standard variance of stock i's return in the estimation window. $L_{1}$ is the length of the estimation window, $\mathrm{R}_{\mathrm{m}}$ is market return on the $\mathrm{T}$ day in the event window, $\overline{R_{m}}$ is the mean of $\mathrm{R}_{\mathrm{nt}}$ in the estimation window.

Cumulative abnormal return (CAR) is the all days'accumulation of the average of all stocks' abnormal return in the event window, which is calculated as follows:

$$
\begin{aligned}
\mathrm{AR}_{\mathrm{T}}=\frac{1}{\mathrm{~N}} \sum_{\mathrm{i}=1}^{\mathrm{N}} \mathrm{AR}_{\mathrm{iT}}, \mathrm{N} \text { is the number of stocks } \\
\operatorname{Var}\left(\mathrm{AR}_{\mathrm{T}}\right)=\frac{1}{\mathrm{~N}^{2}} \sum_{\mathrm{i}=1}^{\mathrm{N}} \operatorname{Var}\left(\mathrm{AR}_{\mathrm{iT}}\right) \\
\mathrm{CAR}=\sum_{T} A R_{T} \\
\operatorname{VAR}(\mathrm{CAR})=\sum_{T} \operatorname{Var}\left(\mathrm{AR}_{\mathrm{T}}\right)
\end{aligned}
$$

Here, $A R_{T}$ is the average of all stocks' abnormal return on the $T$ day. $\operatorname{Var}\left(A R_{T}\right)$ is the variance of $A R_{T}$, $\operatorname{VAR}(\mathrm{CAR})$ is the variance of CAR.

Null hypothesis usually is that the mean of CAR is zero,while alternative hypothesis is that the mean of CAR is not zero. We use the following $t$ test (Subramani and Walden 2001):

$$
\mathrm{J}_{1}=\frac{\mathrm{CAR}}{\{\operatorname{Var}[\mathrm{CAR}]\}^{\frac{1}{2}}} \sim \mathrm{t}(\mathrm{N}-1)
$$

\section{Contribution and Limitations}

The current paper reviewsempirical studies onthe impact of IT investment announcements on firm market value over the years. Through the analysis of existing literature and related theories, an integration model ofthe impact of IT investment announcements onfirm market value is proposed. The current article classifies the factors that affectIT investment value into IT investment characteristics, firm characteristics, competitive environment (including industry characteristics andpartner characteristics), and country characteristics. Each characteristic is elaborated and corresponding hypotheses are proposed. The model gives aclear understanding of the research situation and acomprehensive view of the factors that influence IT investment. This knowledge is helpful for future research. The hypotheses proposed according to the characteristics answer the question of which situation IT investment can get the maximum return. The findings in this paper provide guidance for future empirical research and for the 
decisionmakers of firms.

However, this article also has some limitations. Recent studies indicate that interaction effects are very important for IS (Chin, Marcolin, \&Newsted, 2003). The previous inconsistent results in the empirical researchmay be caused by the lack of consideration of the interactions (Cavaye, 1995, Chin, Marcolin, \&Newsted, 2003). The traditional asset evaluation theory points out that the firms' share prices are adjusted according to IT characteristics, firm characteristics, competitive environment, and country characteristics (Fama and French, 1992)0. The impact of specific IT investments on firm value may vary depending on other characteristics. Therefore, the interaction effectcannot be ignored (Oh et al., 2006). The current article does not discuss the interaction effect in the integrated model because the interaction impact between characteristics has a relationship with the specific project of IT investments. The authors intend to analyze this interaction in the specific empirical research in the future. Although some hypotheseshave been supported by empirical studies, previous studies have rarely considered the five characteristics comprehensively, and the conclusionsare inconsistent on some of the characteristics. In addition, some other characteristics are not touched by empirical studies. Therefore, the integrated model needs further examination, which is the authors' future research direction.

\section{Reference}

Agrawal, M., Kishore, R., \& Rao, H. R. (2006). Market reactions to E-business outsourcing announcements: An event study. Information \& Management, 43(7), 861-873. http://dx.doi.org/10.1016/j.im.2006.08.002

Aral, S., \& Weill, P. (2007). IT assets, organizational capabilities and firm performance: How resource allocations and organizational differences explain performance variation. Organization Science, 18(5), 763-780. http://dx.doi.org/10.1287/orsc.1070.0306

Armstrong, C. P., \& Sambamurthy, V. (1999). Information technology assimilation in Firms: The influence of senior leadership and IT infrastructures. Information Systems Research, 10(4), 304-327. http://dx.doi.org/10.1287/isre.10.4.304

Bakos, J. Y., \& Nault, B. R. (1997). Ownership and investment in electronic networks. Information Systems Research, 8(4), 321-341. http://dx.doi.org/10.1287/isre.8.4.321

Ball, R., \& Brown, P. (1968). An empirical evaluation of accounting income numbers. Journal of Accounting Research, 6(2), 159-178. http://dx.doi.org/10.2307/2490232

Barua, A., \& Mukhopadhyay, T. (2000). Information Technology and Business Performance: Past, Present and Future.In: Zumd R W (Ed), Framing the Domains of IT Management: Projecting the Future through Past. Pinnaflex Educational Resources, Cincinnnati, OH, 65-84.

Basu, A., \& Blanning, R. W. (2003). Synthesis and decomposition of processes in organizations. Information Systems Research, 14(4), 337-355. http://dx.doi.org/10.1287/isre.14.4.337.24901

Berndt, E. R., \& Morrison, C. J. (1994).Assessing the productivity of information technology equipment in the U.S. manufacturing industries.National Bureau of Economic, Researching Working Paper 3582.

Brown, S. J., Warner, J. B. (1985). Using daily stock returns: The case of event studies. Journal of Financial Economics, 14(1), 3-31. http://dx.doi.org/10.1016/0304-405X(85)90042-X

Brown S. J., \& Weinstein M. I. (1985). Derived factors in event studies . Journal of Financial Economics, 14(3), 491-495. http://dx.doi.org/10.1016/0304-405X(85)90010-8

Brynjolfsson, E., \& Hitt, L. (1995). Information technology as a factor of production: The role of difference among Firms. Economics of Innovation and New Technology, 3(4), 183-199. http://dx.doi.org/10.1080/10438599500000002

Brynjolfsson, E., \& Hitt, L. (1996). Paradox lost? Firm-level evidence on the returns to information systems spending.Management Science, 42(4), 541-557. http://dx.doi.org/10.1287/mnsc.42.4.541

Cavaye, A. (1995). User participation in system development revisited. Information and Management, 28(5), 311-323. http://dx.doi.org/10.1016/0378-7206(94)00053-L

Chatfield, A, T., \& Yetton, P. (2000). Strategic payoff from EDI as a function of EDI embeddedness. Journal of Management Information Systems, 16(4), 195-224.

Chatterjee, D., Pacini, C., \& Sambamurthy, V. (2002). The shareholder-wealth and trading-volume effects of information-technology infrastructure investments. Journal of Management Information Systems, 19(2), 7-42.

Chatterjee, D., Richardson, V. J., \& Zmud, R. W. (2001). Examining the shareholder wealth effects of 
announcements of newly created CIO positions. MIS Quarterly, 25(1), 43-70. http://dx.doi.org/10.2307/3250958

Chin, W., Marcolin, B., \& Newsted, P. (2003). Partial least squares latent variable modeling approach for measuring interaction effects: Results from a Monte Carlo simulation study and voice mail emotion/adoption study. Information Systems Research, 14(2), 189-217. http://dx.doi.org/10.1287/isre.14.2.189.16018

Clemons, E., Thatcher, M., \& Row, M.(1995). Identifying sources of reengineering failures: A study of the behavior factors contributing to reengineering risks. Journal of Management Information Systems, 12(2), 9-36.

Clemons, E. K., \& Row, M. C. (1993). Limits to interfirm coordination through information technology: Results of a field study in consumer packaged goods distribution. Journal of Management Information Systems, 10(1), 73-95.

Dardan, S., Stylianou, A.., \& Kumar, R. (2006).The impact of custmer-related IT investment on custmer satisfaction and shareholder returns. Journal of Computer Information Systems, 47(2), 100-111.

Dehning, B., Richardson, V. J., Urbaczewski, A., \& Wells, J. D. (2004). Reexamining the value relevance of e-commerce initiatives. Journal of Management Information Systems, 21(1), 55-82.

Dehning, B., Richardson, V. J., \& Zmud, R. W. (2003). The value relevance of announcements of transformational information technology investments. MIS Quarterly, 27(4), 637-656.

Devaraj, S., \& Kohli, R. (2003). Performance impacts of information technology: Is actual usage the missing link. Management Science, 49(3), 273-289. http://dx.doi.org/10.1287/mnsc.49.3.273.12736

Dewan, S., \& Min, C. (1998). Firm characteristics and investments in information technology: Scale and scope effects. Information Systems Research, 9(3), 219-232. http://dx.doi.org/10.1287/isre.9.3.219

Dewan, S., \& Ren, F. (2007). Risk and return of information technology initiatives: Evidence from electronic commerce announcements. Information Systems Research, 18(4), 370-394. http://dx.doi.org/10.1287/isre.1070.0120

Dos Santos, B. L., Peffers, \& K., Mauer, D. C. (1993). The impact of infomation technology investment announcements on the market value of the firm. Information Systems Research, 4(1), 1-23. http://dx.doi.org/10.1287/isre.4.1.1

Fama, E. F., \& French, K. R. (1992). The cross-section of expected stock returns. Journal of Finance, 47(2), 427-465. http://dx.doi.org/10.2307/2329112

Fergusona, C., Finnb, F., \& Hall, J. (2005). Electronic commerce investments, the resource-based view of the firm, and firm market value. International Journal of Accounting Information Systems, 6(1), 5-29. http://dx.doi.org/10.1016/j.accinf.2004.08.001

Galbraith, J. R. (1977). Organization Design. Reading, MA: Addison-Wesley.

Gurbaxani, V., \& Whang, S.(1991). The impact of information systems on organizations and markets. Communications of the ACM, 34(1), 59-73. http://dx.doi.org/10.1145/99977.99990

Hammer, M. (2001). The superefficient company. Harvard Business Review, 79(8), 82-91.

Harris, S. E., \& Katz, J. L. (1991). Organizational performance and information technology investment intensity in the insurance industry.Organization Science, 2(3), 263-295. http://dx.doi.org/10.1287/orsc.2.3.263

Hayes, D. C., Hunton, J. E., \& Reck, J. L. (2000). Information systems outsourcing announcement: Investigating the impact on the market value of contract-granting firm. Journal of Information Systems, 14(2), 109-125. http://dx.doi.org/10.2308/jis.2000.14.2.109

Hayes, D. C., Hunton, J. E., \& Reck, J. L.(2001). Market reaction to ERP implementation announcements. Journal of Information Systems, 15(1), 3-18. http://dx.doi.org/10.2308/jis.2001.15.1.3

Hill, C. A., \& Scudder, G. D. (2002). The use of electronic data interchanges for supply chain coordination in the food industry. Journal of Operations Management, 20(4), 375-387. http://dx.doi.org/10.1016/S0272-6963(02)00017-7

Horton, K. S. (2003). Strategy, practice, and the dynamics of Power. Journal of business research, 56(2), 121-126. http://dx.doi.org/10.1016/S0148-2963(01)00284-3

Im, K. S., Dow, K. E., \& Grover, V. (2001). Research report: A reexamination of IT investment and the market value of the firm - An event study methodology. Information Systems Research, 12(1), 103-117. http://dx.doi.org/10.1287/isre.12.1.103.9718

Jarvenpaa, S. L., \& Leidner, D. E. (1998). An information company in Mexico: Extending the resource-based view of the firm to a developing country context. Information Systems Research, 9(4), 342-361. 
http://dx.doi.org/10.1287/isre.9.4.342

Jasperson, J., Carte, T. A., Saunders, C. S., Butler, B. S., Croes, H. J. P., \& Zheng, W. (2002). Power and information technology research: A metatriangulation review. MIS Quarterly, 26(4), 397-459. http://dx.doi.org/10.2307/4132315

Jorgenson, D. W., Ho, M. S., \& Stiroh, K. J. (2003). Growth of U.S. industries and investments in information technology and higher education. Economic Systems Research, 15(3), 279-325. http://dx.doi.org/10.1080/0953531032000111781

Keen, P. G. W. (1988). Competing in time using telecommunications for competitive advantage. Cambridge: Ballinger Publishing Company.

Kettinger, W. J., Grover, V., Guha, S., \& Segars, A. (1994). Strategic information systems revisited: A study in sustainability and performance. MIS Quarterly,18(1), 31-58. http://dx.doi.org/10.2307/249609

Khallaf, A., \& Skantz, T. R. (2007). The effects of information technology expertise on the market value of a firm. Journal of Information Systems, 21(1), 83-105. http://dx.doi.org/10.2308/jis.2007.21.1.83

Kraemer, K. L., Dedrick, J., \& Yamashiro, S. (2000). Refining and extending the business model with information technology: Dell Computer Corporation. The Information Society, 16(1), 5-21. http://dx.doi.org/10.1080/019722400128293

Lee, H. G., Cho, D. H., \& Lee, S. C. (2002). Impact of e-business initiatives on firm value. Electronic Commerce Research and Applications, 1(1), 41-56. http://dx.doi.org/10.1016/S1567-4223(02)00005-4

Lin, J. C., Jang, W. Y., \& Chen, K. J. (2007). Assessing the market valuation of e-service initiatives. International Journal of Service Industry Management, 18(3), 224-245. http://dx.doi.org/10.1108/09564230710751460

Loveman, G. W. (1994). An assessment of the productivity impact of information technologies. Cambridge: Oxford University press.

Lucas, H. (1999). Information tchnology and the poductivitypradox: The search for value. Oxford: Oxford University Press.

Mascarenhas, B. (1992). First mover effects in multiple dynamic markets. Strategic Management Journal, 13(3), 237-243. http://dx.doi.org/10.1002/smj.4250130306

Melville, N., Kraemer, K., \& Gurbaxani, V. (2004). Review: Information technology and organizational performance: An integrative model of IT business value. MIS Quarterly, 28(2), 283-313.

Meng, Z. L., \& Lee, S. Y. (2007). The value of IT to Firms in a developing country in the catch-up process: An empirical comparison of China and the United States. Decision Support Systems, 43(3), 737-745. http://dx.doi.org/10.1016/j.dss.2006.12.007

Mukhopadhyay, T., \& Kekre, S. (2002). Strategic and operational benefits of electronic integration in B2B procurement processes. Management Science, 48(10), 1301-1313. http://dx.doi.org/10.1287/mnsc.48.10.1301.273

Neo, B. S. (1988). Factors facilitating the use of information technology for competitive advantage: An exploratory study. Information and Management, 15(4), 191-201. http://dx.doi.org/10.1016/0378-7206(88)90045-6

Oh, W., \& Gallivan, M. J. (2004). An empirical assessment of transaction risks of It outsourcing arrangement: An Event Study. In: Proceedings of the 37th Hawaii International Conference on System Sciences.

Oh, W., Gallivan, M. J., \& Kim, J. W. (2006). The market's perception of the transactional risks of information technology outsourcing announcements. Journal of Management Information Systems, 22(4), 271-303. http://dx.doi.org/10.2753/MIS0742-1222220410

Oh, W., Kim, J. W., \& Richardson, V. J. (2006). The moderating effect of context on the market reaction to IT investment. Journal of Information Systems, 20(1), 19-44. http://dx.doi.org/10.2308/jis.2006.20.1.19

Peak, D. A., Windsor, J. C., \& Conover, J. (2002). Risks and effects of IS/IT outsourcing: A securities market assessment. Journal of Information Technology Cases and Applications, 4(1), 6-33.

Porter, M. E., \& Millar, V. E. (1985). How information gives you competitive advantage. Harvard Business Review, 63(4), 149-160.

Ranganathan, C., \& Brown, C. V. (2006). ERP investment and the market value of Firms: Toward an understanding of influential ERP project variables. Information Systems Research, 17(2), 145-161. http://dx.doi.org/10.1287/isre.1060.0084 
Richardson, V. J., \& Zmud, R. W.(2002). The Value Relevance of Information Technology Investments Announcements: Incorporating Industry Strategic IT Role. In Proceedings of the 35th Hawaii International Conference on System Science. USA, Hawaii. http://dx.doi.org/10.1109/HICSS.2002.994251

Riggins, F. J., \& Mukhopadhyay, T. (1994). Interdependent benefits from interorganizational systems: Opportunities for business partner reengineering. Journal of Management Information Systems, 11(2), 37-57.

Ross, J. W., Beath, C. M., \& Goodhue, D. L. (1996). Develop long-term competitiveness through IT assets. Sloan Management Review, 38(1), 31-42.

Sabherwal, R., \& Sabherwal, S. (2005). Knowledge management using information technology: Determinants of short-term impact on firm value. Decision Sciences, 36(4), 531-567. http://dx.doi.org/10.1111/j.1540-5414.2005.00102.x

Sabherwal, R., \& Sabherwal, S. (2007). How do knowledge management announcements affect firm value? A study of Firms pursuing different business strategies. IEEE Transactions on Engineering Management, 54(3), 409-422. http://dx.doi.org/10.1109/TEM.2007.900785

Sambamurthy, V. A., \& Bharadwaj, V. G. (2003). Shaping agility through digital options: Reconceptualizing the role of information technology in contemporary Firms. MIS Quarterly, 27(2), 237-263.

Schein, E. H. (1992). The role of the CEO in the management of change: The case of information technology. Oxford: Oxford University Press.

Schumpeter, J. A. (1950). Capitalism, socialism, and democracy. New York: Harper.

Smith, C., \& Watts, R. (1992).The investment opportunity set and corporate financing, dividend, and compensation policies. Journal of Financial Economics, 32(3), 263-292. http://dx.doi.org/10.1016/0304-405X(92)90029-W

Straub, D. W., \& Watson, R. T. (2001). Transformational issues in researching IS and Net-enabled organizations. Information Systems Research, 12(4), 337-345. http://dx.doi.org/10.1287/isre.12.4.337.9706

Porter, M. E. (1985).Competitive Advantage: Creating and Sustaining Superior Performance. New York: Free Press.

Subramani, M., \& Walden, E. (2001). The impact of e-commerce announcements on the market value of Firms. Information Systems Research, 12(2), 135-154. http://dx.doi.org/10.1287/isre.12.2.135.9698

Teo, T. S. H., Wong, P. K., \& Chia, E. H. (2000). Information technology (IT) investment and the role of a firm: An exploratory study. International Journal of Information Management, 20(4), 269-286. http://dx.doi.org/10.1016/S0268-4012(00)00016-5

Wade, M., \& Hulland, J. (2004). Review: The resource-based view and information systems research: Review, extension, and suggestions for future research. MIS Quarterly, 28(1), 107-142.

Williams, M. L., \& Frolick, M. N. (2001).The evolution of EDI for competitive advantage: The FedEx case. Information Systems Management, 18(2), 47-53. http://dx.doi.org/10.1201/1078/43195.18.2.20010301/31277.8

Zuboff, S. (1988). In the age of the smart machine.The future of work and power. New York: Basic Books.

Table 1. Statistics of Research Papers

\begin{tabular}{llllllll}
\hline Research Objects & MISQ & ISR & JMIS & DSS & JIS & Others & Total \\
\hline Investment Related IT & 1 & 2 & 1 & 1 & 1 & 2 & 8 \\
E-Business & 0 & 2 & 1 & 0 & 0 & 3 & 6 \\
Enterprise System & 0 & 1 & 0 & 0 & 1 & 0 & 2 \\
Knowledge Management & 0 & 0 & 0 & 0 & 0 & 2 & 2 \\
IT Outsourcing & 0 & 0 & 1 & 0 & 1 & 3 & 5 \\
IT Staff & 1 & 0 & 0 & 0 & 1 & 0 & 2 \\
Total & 2 & 5 & 3 & 1 & 4 & 10 & 25 \\
\hline
\end{tabular}

Others include Journal of Computer Information Systems, Hawaii International Conference on System Science, Electronic Commerce Research and Applications, International Journal of Accounting Information Systems, Decision Sciences, IEEE Transactions on Engineering Management, Journal of Information Technology Cases and Applications, Information and Management. 


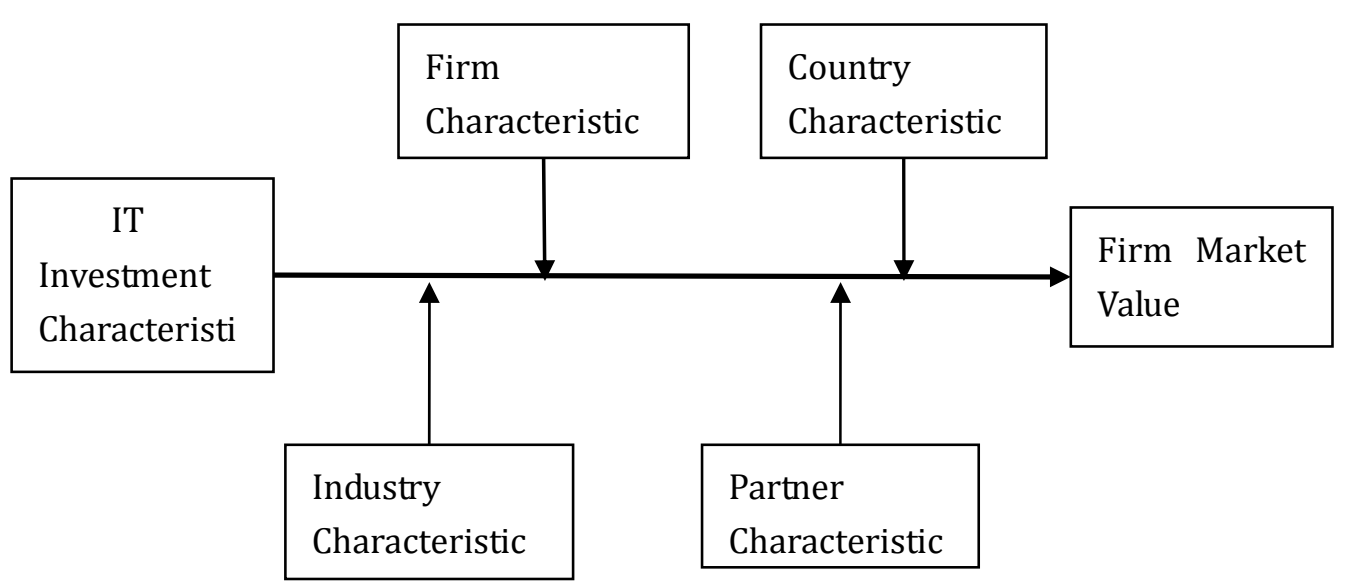

Figure 1. The Integration Model of Impact of IT Investment Announcements on the Market Value of Firms 